\title{
BP’S USE OF POSTURE TO RESPOND TO THE DEEPWATER HORIZON CRISIS
}

\author{
Vida Goosen-Botes+ \\ University of Waikato, Hamilton, New Zealand \\ vidab@waikato.ac.za \\ Grant Samkin" \\ University of Waikato, Hamilton, New Zealand \\ grantsam@waikato.ac.za
}

Received: April 2012

Accepted: February 2013

\begin{abstract}
This paper focuses on the posture the oil company BP adopted when faced with a legitimacy crisis during one of the worst environmental disasters in history. Against a backdrop of a discussion of the rhetorical aspects of image repair discourse and organisational legitimacy, Hearit's strategy of corporate apologia was employed to determine the posture BP adopted in relation to the crisis. This paper adds to the literature on image repair strategies by heeding a call by Hearit for the context within which corporate apologia takes place to be taken account of, an approach that warrants a distinct line of research. The literature was further extended by complementing Hearit's strategy with semiotics and analysing its use in both the annual and sustainability reports. The additional focus on the sustainability reports is important, due to the high premium placed on sustainability in the changing business environment. On a practical level this paper contributes to an understanding of how organisations use sustainability reports to respond to legitimacy challenges.
\end{abstract}

Keywords

Legitimacy; sustainability reports; crisis response, visual images

+ Dr Vida L Goosen-Botes is a research developer in the Waikato Business School, University of Waikato, Hamilton, New Zealand.

\#Dr J Grant Samkin is an associate professor in the Institute for Business Research, University of Waikato, Hamilton, New Zealand. 


\section{INTRODUCTION}

The objective of this paper is to determine the posture BP adopted in its 2010 annual and sustainability reports in response to the Deepwater Horizon crisis. Using Hearit's apologia strategy and incorporating an analysis of the images in both 2010 annual and sustainability reports, this study will detail the different postures adopted by BP during the crisis.

In recent years the role companies play in society has changed significantly (Botes, 2006). No longer are they seen as existing primarily to deliver economic benefits for shareholders, but functioning as an integral part of society. This has been described as operating in a triple context - that is, operating within three interdependent sub-systems: the global economic, social and political, and natural environmental systems.

How organisations respond to crises has been extensively covered in the academic literature (recent examples in the accounting literature include Benoit \& Henson (2009), Coombs (2007), Glantz (2010) and Svensson (2009)). When a crisis occurs, the reputation of the organisation may be irrevocably damaged, leading to its legitimacy being questioned. The 2010 oil spill in the Gulf of Mexico, known as the Deepwater Horizon incident, is an example of an environmental disaster that caused the legitimacy of BP to be questioned. As a result of the disaster, BP suffered extensive reputational damage. Even during the incident, additional events occurred that caused the public to further question BP's right to exist. Support from certain stakeholders was noticeably absent and the company faced a crisis. BP CEO Bob Dudley acknowledged this by explaining that the unprecedented oil spill had significant consequences for jobs, businesses, communities, the environment and the oil industry (BP Sustainability Review, 2010).

The nature, consequences and impact of the Deepwater Horizon disaster were so significant that there is likely to be numerous research papers in different disciplines dedicated to the incident. From an accounting perspective studies can already be found in published conference proceedings and in journals. For example, Summershay and De Villiers (2012) reviewed the impact that the incident had on annual reports disclosures made by oil companies post spill, while Smith, Smith and Ashcroft (2010) estimated the financial costs to BP as well as the environment, including the loss of sea life such as birds, sea turtles and mammals.

Benoit (1997) describes how carefully crafted communication can be used to re-establish corporate legitimacy. Previous studies (see for example Clarke (2005), Deegan, Rankin \& Tobin (2002); Hooghiemstra (2000); Ogden \&; Samkin, Allen \& Wallace (2010) and Samkin \& Schneider (2010)) have illustrated how communication instruments, including annual reports, sustainability reports and web-sites, have been used to influence or manage corporate image or reputation when a crisis is responded to. How various communication strategies can be used by an organisation to legitimise its actions is therefore of interest to managers, shareholders as well as other stakeholders.

Typologies of image restoration strategies used to repair organisational legitimacy have been considered previously by Benoit and Brinson (1999), Brinson and Benoit (1999), Barton (2001), Benoit and Henson (2009), and Glantz (2010), and Hearit (1995). Complementing these studies are Hearit (1995) and Hearit and Brown (2004), who examined how organisations can make use of apologia in the midst of a public relations crisis or when responding to criticism. While Benoit (1995), Goffman (1971) Snyder, Higgings and Stucky (1983), and Ware and Linkguel (1973) have focused on the messages used by organisations to restore their legitimacy, studies that have examined the context in which the posture was adopted when the apologia occurred are limited. 
By studying apologia in the annual and sustainability reports, this study is a direct response to Hearit's (1995) call for establishing research into posture or stance adopted during corporate apologia as a distinct line of research. As Hearit (2006:70) further explains, not only does language use impact on the quality of corporate responses to criticisms, but the symbolic, ritual and temporal factors can and do play their part as well. For this reason semiotics is used in this study to complement Hearit's apologia strategy.

Although use of apologia when responding to a crisis is not new (see for example Benoit (1997), Coombes (2007), Taylor (2009) and Vasquez \& Taylor (2001) who have all studied the use of apologia), none of the previous studies used apologia to analyse corporate annual reports. This study extends the previous studies that have focused on the disclosures made in the annual reports of organisations when they are responding to a crisis (see for example, Deegan, Rankin \& Tobin (2002) and Summerhays \& de Villiers (2012)) in that it focuses on the use of apologia in both the annual and sustainability reports. The inclusion of the sustainability report is important due to the high premium placed on this in the modern business environment (Ecceles \& Krzus, 2010).

This paper is structured as follows. An overview of organisational legitimacy will be provided before Hearit's discourse strategy of apologia is discussed. An overview of semiotics follows. Following this, the background to the Deepwater Horizon incident will be introduced as a precursor to the application of Hearit's apologia strategy. Two particular events that occurred during the incident and were highlighted by the media, and which further challenged BP's legitimacy, are included to contextualise the study. The research design is then detailed, before the verbal and visual communication contained in the annual and sustainability reports is discussed and analysed to establish which postures BP adopted in responding to the legitimacy crisis. The conclusion rounds out the paper.

\section{ORGANISATIONAL LEGITIMACY}

From an organisational perspective, legitimacy has been described by Dowling and Pfeffer (1975, p. 122) as

a condition or status which exists when an entity's value system is congruent with the value system of a larger social system of which the entity is a part. When a disparity, actual or potential, exists between the two values, there is a threat to the entity's legitimacy.

Epstein (1972), for his part, stressed that organisations will be perceived as legitimate only if they are seen to conduct their operations in a useful and responsible manner.

Legitimacy theory is based on the premise of a social contract, where the organisation requires a positive relationship with the organisation to ensure access to resources or a licence to operate (Shocker \& Sethi, 1974). What this means is that in order to survive and prosper, organisations must derive economic support in the form of raw material supply and labour, as well as societal support from the community in which they operate and political support.

More recently, legitimacy has been described by Schuman (1995:574) as “... a generalised perception or assumption that the actions of an entity are desirable, proper, or appropriate within some socially constructed system of norms, values, beliefs and definitions". That is, legitimacy decisions are based on messages in the public arena (Allan \& Caillouet, 1994). Yoon (2005:765) goes as far as to suggest that "legitimacy may be a reflection of whether an organisation has the competence and resources necessary for achieving its goals". Legitimacy then can be viewed as an essential organisational resource. What this means is that while the 
organisation's goals and means are congruent with societal norms, society will continue to provide it with a sufficient level of support to ensure its survival (Metzler, 2001; Ogden \& Clarke, 2005).

In addition to competence, organisations should also fulfil a community requirement (Hearit, 1995). That is, their actions should be "ethically defensible" (Hearit, 1995:3) or morally legitimate (Schuman, 1995). This ethical dimension focuses on how the organisation's policies affect the larger social system in which it operates (Hearit, 1995; Schuman, 1995) or how responsive the organisation is to stakeholders' concerns (Georgio \& Jack, 2011). It therefore follows that the community should subject the organisation to social sanction when it fails to "act, or at least speak, in a responsible manner that warrants public acceptance and acquiescence (e.g., not break the law or not put people at risk to profit unnecessarily)" (Hearit, 1995:3).

Following this, challenges to legitimacy take two forms, namely performance and value challenges (Hearit, 1995; Hirsh \& Andrews, 1984). More recently Boyd (2000) has extended the concept of legitimacy to distinguish between 'institutional legitimacy' and 'actional legitimacy'. The difference between institutional legitimacy and actional legitimacy has been succinctly summarised by Boyd (2000:348) as follows:

If institutional legitimacy matters at the macro level of analysis, actional legitimacy matters at the micro level of analysis. Actional legitimacy is achieved when an action is perceived by publics as being undertaken within the institution's realm of authority and thus inspires public confidence in the institution.

\section{SOCIAL LEGITIMATION CRISES AND THE USE OF IMAGE REPAIR STRATEGIES}

According to Rogers, Dillard and Yuthas (2005), the image of the organisation helps to establish its reputation. If the image is grounded in authentic traits or attributes, then it will provide a legitimate basis for society to judge the organisation. Essentially what this means is that where organisations fail to act in the public interest they face a legitimacy crisis. A clear indication of the existence of a legitimacy crisis is the following, according to Hearit (1995:3):

Is the emergence of public animosity toward the corporation? This hostility is a form of a social sanction by which the supra-system (e.g., media, opinion-leaders, consumers, etc.) in effect says, "We don't approve of what you have done".

Legitimacy crises impact on how stakeholders view and interact with the organisation. Rather than ignoring criticism Hearit (2006, p. 13) explains that organisations need to respond in such a manner that this counterinfluences public opinion. The high premium placed by organisations on legitimacy means that when faced with legitimacy crises entities respond to either "right" or defend the wrong (Hearit, 1995). The ways that organisations faced with challenges to their legitimacy can respond have been widely discussed in the literature (see for example Benoit \& Henson (2009), Coombes, (2007), Glantz, (2010), Hearit, (1995), Metzler (2001) and Svensson (2009)). One way in which organisations can "extricate themselves from difficult straits" (Hearit, 2006:vii) is a typology based on a preventative and restorative approach to image management. It has as its core the ability firstly to identify the type of attack on the legitimacy of the organisation and then present five image repair strategies. These are: denial; evasion of 
responsibility; reducing the offensiveness of the event; corrective action; and mortification (Benoit, 1997:179).

Hearit's (2006) approach to image restoration focused on a study of the language used, and posture adopted by the perpetrator of the crisis. Hearit's (2006) approach distinguished between the terms apology and apologia. Hearit (2006:5) explains that an "apologia is not an apology (although it may contain one), but a defence that seeks to present a compelling, counter description of organisational actions". Strategies for apologia are more fully described Maresh and Williams (2010:287) as follows:

\begin{abstract}
Attempts at denial are frequently used to avoid responsibility, while counterattack challenges the ethics of accuracy of the accusing group. Apology is used when other options are not feasible and may or may not include a request for forgiveness. The legal strategy has the accused organization say as little as possible, or denying or shifting the blame for the crisis.
\end{abstract}

While an apology typically means acknowledging one's mistakes, apologia is a character-based defence where success depends on the persona of the spokesperson. As organisations are not individuals, but juristic persons, the posture adopted by the spokesperson will indicate the posture or stance the organisation adopts (Hearit, 1994). (See posture and self-validation theory.) In an attempt to address the dearth of information surrounding the context in which the apologia happened, Hearit (2001) focused on the postures enacted by apologists when responding to allegations of wrongdoing. Drawing on Benoit (1995), Fitzpatrick and Rubin (1995), and Ware and Linkugel (1973), Hearit (2001) identified five postures organisations can adopt when an image restoration strategy is required. These postures are summarised in TABLE 1.

\title{
TABLE 1: Postures of apologia
}

\section{Denial}

a. We are not guilty.

b. Our actions were not intentional.

c. We fear liability therefore we deny guilt irrespective of public evidence

2. Counterattack

Deny guilt and attempt to transfer it to the accusers

\section{Differentiation}

a. Transfer guilt from organisation to an individual (scapegoat).

b. Defeasibility

\section{Apology}

\section{Acknowledge because you have no choice but do not acknowledge responsibility}

\section{Legal}

Critics do not fully understand "all the facts"

Source: Adapted from Hearit (2001) 
While Benoit's (1997) framework is based on the key strategic messages presented when dealing with a crisis situation, Hearit's (2001) focus is on the posture of the apologist. These five stances are considered in further detail below.

\subsection{Denial}

When using a denial strategy a number of options are available to the organisation. First, the organisation states that it is not guilty of the wrongdoing. Second, there was no intention for anything bad to happen. This was the approach adopted by Johnson and Johnson when seven people died after taking Tylenol contaminated with cyanide (Benoit \& Lyndsey, 1987). This strategy makes use of an opinion-knowledge dissociation to deny guilt. That is, organisations claim that any discussion of wrongdoing is "mere opinions" rather than knowledge of the facts (Hearit, 1994). In the final denial subcategory organisations make use of a defensive strategy out of fear of liability, irrespective of public evidence.

\subsection{Counterattack}

Using a counterattack strategy, organisations deny that they are guilty of the wrongdoing while accusing their critics of being unethical for making the allegations. In other words, organisations deal with their guilt through denial and by attempting to transfer it to the accusers. This stance is often used by unethical companies attempting to "extricate themselves from criticism - or at least muddy the waters a bit" (Hearit, 2001:505). A counterattack stance can be very risky, as it can portray the company as being aggressive.

\subsection{Differentiation}

Under a differentiation stance, an organisation transfers its guilt to a scapegoat. The argument used is that the scapegoat, often an individual, acted on his/her own behalf without organisational sanction (Hearit, 2001). By having a scapegoat that can be disciplined, the organisation plays the role of an innocent. Hearit (2001) explains that the differentiation can also refer to the strategy where the blame is not shifted, but the situation is no longer feasible. Schultz and Seeger (1991) use the example of the Chrysler Corporation going back on its word to continue operating in Wisconsin by stating that market conditions no longer made the operation feasible.

\subsection{Apology}

Another stance organisations take when dealing with their guilt is to apologise. This occurs when the organisation recognises that it has no other choice. Due to liability issues, however, statements of apology tend to be ambiguous, and are framed as regret rather than asking for forgiveness. They are carefully crafted to avoid any acknowledgement of the organisation's full responsibility (Hearit, 1994).

\subsection{Legal}

The final posture that can be adopted is a legal one. Under this stance guilty companies take a legal stance towards the accuser. Taking this stance suggests that the organisation acknowledges that its problems will have a long-term impact and consequently it has turned the matter over to its lawyers. Kaufman, Kesner and Hazen (1994) provide an example of this stance 
when they described how the Ford Motor Company used the courts to defend itself against accusations that the Pinto model exploded on impact when involved in a rear-end collision.

\section{VISUAL RHETORIC: SEMIOTICS AS A COMPONENT OF COMMUNICATION}

There has been an increase in the use of both "visual and verbal vocabulary" when environmental matters are reported on (Frandsen \& Johansen, 2011:4). Rhetoric has been described as a system of strategies that can be used to create, react to, and receive meaning (Hocks, 2003). Scott (1994:252) describes rhetoric as "an interpretive theory that frames a message as an interested party's attempt to influence an audience." As Hearit's (1995) theory of apology focuses on non-verbal communication as the primary resolution to a legitimacy crisis, it provides an alternative strategy that can be used when studying image repair rhetoric. When organisations face legitimacy challenges, communication as a form of rhetoric is often played out in the media.

Rhetoric is not restricted to verbal and written communications, but includes images. Images are becoming increasingly important to organisations (Cheney, 1992). Analysing posture in images can convey meaningful information (Jiang, Li and Drew, 2007). For example, Kress (2006) states that the position in which a subject is placed in a photograph and whether the background is blurred or clear will disclose information about the importance of the subject. Self-validation theory can be used to explain how posture provides substantial amounts of nonverbal information about emotions (Briñol, Petty \& Wagner, 2009). Alvesson (1990) explains that corporations build legitimacy by influencing an image, and it follows, then, that posture adopted in the images in annual and sustainability reports will reveal information about the strategy the company adopted when dealing with crisis communication.

While Hearit's strategy of apologia does consider communication, it does not specifically consider the use of visual images. One way of analysing how visual images reinforce image repair discourse utilising apologia is through semiotic analysis. According to Moriarty as quoted by Samkin et al. (2010:26), semiotics is the study of "signs that are used in producing, conveying and interpreting messages and the codes that govern their use." Eco (1979) explains that signs as a subset of semiotic study, take into account the common use of language. Semiotics can also be applied to images. Images, according to Scott (1994:252), are not merely a reflection of real world objects but have symbolic or mental meaning. While Heller (2004) acknowledges that images are defined by the role that they play in commerce and culture, he also says that images created by graphic designers are presented "as expressions of specific needs or solutions to distinct problem". Heller further classifies images into categories, one of which he identifies as persuasion. These are images designed "in service of control and influence".

Samkin et al. (2010) indicate that it is important to note both the paradigmatic and syntagmatic dimensions when examining images constructed for specific purposes. Paradigmatic refers to choices made when the particular image is constructed (choosing for example a particular colour of hair from amongst all colours available), while syntagmatic refers to arrangement of the signs within the image. If the images and the text used in image repair discourse are to be clearly understood, they need to be seen against a specific backdrop or context. The next section will discuss the research design and data sources before providing an overview of the Deepwater Horizon environmental disaster. 


\section{RESEARCH DESIGN AND DATA SOURCES}

The subjects of this study are the 2010 annual and sustainability reports obtained from BP's website. The research involves a detailed examination of the non-financial disclosures contained in these documents with a particular emphasis on the images. The annual and sustainability reports for the 2009 reporting period were also examined to further contextualise the study.

Non-financial disclosures as a form of communication strategy used by organisations in their annual reports have been the subject of extensive research (see for example Abrahamson \& Park, 1994; Deegan et al., 2002; and Summerhays \& de Villiers, 2012). Annual reports can be seen as "representative of a firm's broad array of communication channels and may offer insights into an organisation's approach to managing symbolically important stakeholders' perception of the firm and of the top management" (Samkin et al., 2010:31). The non-financial communication and images contained in these reports were specifically focused on in order to apply Hearit's apologia theory, which focuses on posture.

This study takes the form of a case study of a single crisis incident in BP's history. The Deepwater Horizon incident was chosen, as the live video feed of the environmental disaster made this crisis a unique incident. Sigglekow (2007) argues that using a case study to obtain insights from a unique incident is appropriate. This case study attempts to obtain insights into BP's posture during crisis communications. The selection of BP for this study was further motivated by the fact that it represented an organisation which had already been found guilty by the public even before the investigation into the incident had been complete. Hearit's (1995) approach makes BP particularly suited to the application of apologia focusing on posture.

\section{DATA SOURCES}

The annual reports of companies are both a legal requirement and are also used as a way of communicating the organisation's accountability to stakeholders. BP's annual and sustainability reports for the reporting period ending 31 December 2010 (http://www.bp.com) were accessed electronically, and the non-financial disclosures (including the postures taken in images within these reports) carefully considered. Over the period of the incident BP engaged in several forms of communication with stakeholders, including the use of press releases, interviews on the radio and television and maintaining information on its website (as detailed in Annexure A). The Factiva database was used to find relevant press releases on the Deepwater Horizon crisis. A Google search using the term BP was launched to determine the extent of media interest in the events during the crisis. The growing importance attached to the credibility of independent opinions expressed through informal media sources (Litvin, Goldsmith and Pan, 2007) resulted in the inclusion of blogs as sources of data. A Google search using the terms 'live video feed' (spillicam) and 'altered images' identified blogs that could be examined in order to obtain opinions of stakeholders (other than the shareholders) who had been affected by the crisis. As management have complete editorial control over the content of the annual report, and by association the sustainability report (Samkin, 2012), the stance BP took in these documents when responding to the Deepwater Horizon crisis would represent the company's posture. This study includes a focus on semiotics utilised in these reports. 


\section{AN OVERVIEW OF THE DISASTER}

On 20 April 2010 explosions on the Deepwater Horizon, a fifth-generation, dynamically positioned semi-submersible drilling unit operating in the Gulf of Mexico, killed 11 workers and injured 17 others (BP Sustainability Review, 2010). At least three million barrels of oil were spilt into the sea. In addition to the death and injuries, extensive damage was caused to marine and wildlife habitats as well as fishing and tourism (see Annexure B). What made the Deepwater Horizon disaster different to other environmental disasters was that for the first time in history the public could view live streaming as the event happened (Black, 2010).

The Deepwater Horizon oil spill was not BP's first major industrial accident that resulted in the deaths of employees and damage to the environment. BP had been involved in two other catastrophic incidents, both of which had been linked to cost-cutting at the expense of worker safety and environmental stewardship. The first in 2005 at BP's Texas City oil refinery resulted in the death of 15 workers, with a further 180 injured (Magner, 2011). This cost the company US\$2 billion in damages and lawsuits (Bryant and Hunter, 2010). The second was the discovery on 2 March 2006 of a corroded pipe near Prudhoe Bay, Alaska. This resulted in 212252 gallons of crude being discharged into 1.93 acres of tundra and frozen lake surface (Magner, 2011). The company was fined $\$ 25$ million dollars and had to pay $\$ 255$ million to the state of Alaska over oil-production shortfalls caused by the spills (Sweet, 2012).

The Deepwater Horizon was reputably owned and operated by Transocean Offshore Deepwater Drilling Incorporated. The drilling unit had been leased by BP to complete the Macondo Well, 77 kilometres from the Louisiana coast in the Gulf of Mexico (de Gravelles \& de Gravelles, 2011). After drilling to its final depth of 18360 feet, the drilling contractor company, Halliburton, cemented the well despite the fact that it was commercially viable. The cement was supposed to protect the well bore from escaping oil and gas. As a result of a number of errors, oil and gas vented onto the rig, causing the heating ventilator and oil air conditioning systems to carry a gas-rich mixture into the engine room. Two explosions resulted. The ensuing fire lasted for the thirty-six hours it took the Deepwater Horizon to sink (de Gravelles \& de Gravelles, 2011).

Initial estimates of the oil spill varied widely, ranging from a conservative 1000 barrels a day to between 35000 to 60000 barrels per day (King, 2010). Eighty-six days later an estimated 4.9 million barrels of oil had leaked into the Gulf of Mexico. Over 400 species of wildlife and hundreds of meters of fragile coastline had been destroyed (Guarino, 2010). Annexure B contains an estimate of environmental damages to external parties prepared by Smith, Smith and Ashcroft (2010). Following the initial estimates of $\$ 36.9$ billion, BP raised its provision for the disaster in 2013 to $\$ 42.2$ billion after its profits released in the 2012 annual reports had halved to $\$ 12$ billion (Gosden, 2013).

The three companies, BP, Transocean and Halliburton, blamed each other for the disaster, while Transocean also blamed Cameron, a manufacturer of valves (Milbank, 2010). Others blamed the Department of Minerals Management Services for rubberstamping BP's drilling projects without ensuring that a proper response plan was in place in case of an oil spill (Eilperin, 2010). A timeline of the most important events during the Deepwater Horizon crisis, garnered from the search of a number of different data sources (Annexure A), was constructed. During the crisis two events gained a lot of media attention and as a precursor to the application and analysis of Hearit's strategy of apologia these events will first be discussed in greater detail. 


\subsection{Event 1: CE0, Tony Haywood and the live video feed}

The Deepwater Horizon spill was not the first oil spill in the gulf (in June 1979 Mexican stateowned oil company Pemex had a massive blowout, resulting in the worst oil spill in history at that point) nor has it been the worst US environmental disaster (the Dust bowl of the 1930s was worse) (About.com, 2010). What made the Deepwater Horizon disaster different was that for the first time in history the public could view live streaming of an environmental disaster on television (Black, 2010).

At the start of the Deepwater Horizon oil spill, CEO of BP Tony Hayward suggested that "the massive Gulf of Mexico oil spill will end up having only a very, very modest environmental impact" (Scare, 2010). Initially the US coast guard seemed to support this, but three days later, in a reverse statement, officials started warning of an environmental disaster (BBCNews, 2010). Black (2010:743) claimed that in the interests of transparency proof was required of the significance of the spill because "frankly, an oil company was the last voice we were willing to trust". Black (2010) further described how the Whitehouse insisted that the Deepwater Horizon leak should be shown to the American public via live video feed, saying "this may be BP's footage, but it's America's ocean". The television footage from the live video feed shown to the American public was likened to a horror film (Stuever, 2010). In a Washington Post article with a headline "BP Present: One Slick Horror Film", Stuever (2010) describes how the viewer sits spellbound watching the inexorable, unending flow of the leak. Without the footage of the leak BP would have been able to manage the image of the spill while denying its reality (Black, 2010). The evidence from the live video feed provided the world with the opportunity to bypass corporate, or even government, misinformation (Black, 2010).

Tony Hayward visited Louisiana and attempted to apologise to the public for the oil spill disaster with the following comment to reporters: "We're sorry for the massive disruption it's caused their lives. There's no one who wants this over more than I do. I would like my life back" (Times Online, 2010). The comment was received by public and in particular those on the Gulf of Mexico Gulf coast with utter disbelief. The comments were seen as insensitive, and Haywood out of touch with reality, especially as many on the coast felt that BP had destroyed their way of life (Times Online 2010) (The impact of the financial and other environmental costs on the Gulf of Mexico are illustrated in Annexure B.) The public's anger was evident on blog spots, with observations including "Hayward's comments are baffling as he's not even trying to hide the fact that he's only looking out for Number One" (Huffingtonpost, 2010). The comment is just one in a string of out-of-touch statements made by Hayward, including when he called the spill "relatively tiny" (Summers, 2010). Anger at Hayward's comment that the environmental impact of the dispersant used to clean-up the oil spill would be modest was also apparent in the Times Online (2010). Hayward further angered the public by taking issue with the findings of three independent and separate scientific teams, which stated that there were vast oil plumes below the surface of the sea and that there was no evidence that the oil was only on the surface (Associated Press, 2010).

On 18 June 2010 Hayward appeared in front of the US Congress and was severely chastised over the spill. Criticism of the way in which he handled the event led to him negotiating his exit from the company. When the BBC revealed that Hayward would receive a year's salary benefits worth more than one million pounds (US\$1 600000 ) and an annual pension of 600000 pounds (US\$980 000 ) when he retired in two years' time, there was further public outcry. 


\subsection{Event 2: Altered images of Gulf oil spill}

After the new appointment of Dudley as the new Chief Executive Officer (CEO), when BP was starting to get to grips with the multitude of problems associated with sealing the leaking oil well, another storm broke loose, this time around altered photographs released by BP. During the course of the crisis, BP had released numerous photographs to the public, aimed at providing a glimpse of the oil spill and clean-up efforts.

BP admitted to altering oil spill images after a US Blogger on Americablog.com identified tampered images. In one image a BP helicopter was shown as flying over the coast to monitor the oil spill (Korosec, 2010). The Blogger highlighted a number of problems with the image. These not only contradicted the appearance of flying, but also suggested that the ocean was much bluer than in the original photograph (Hough, 2010). Amerciablog also "uncovered a photo on BP's site that appears to be of the operations centre from 2001, which was altered to make it look like it was a recent photograph" (Raby, 2010).

\section{IMAGE 1: Altered image of helicopter}

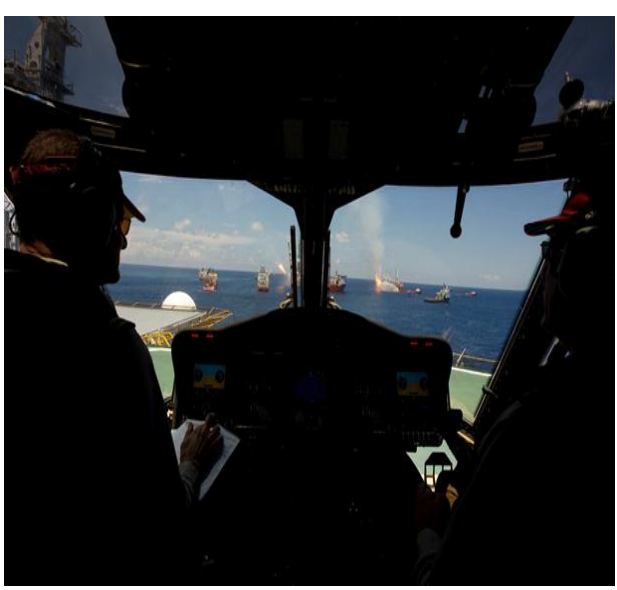

Before the image was altered

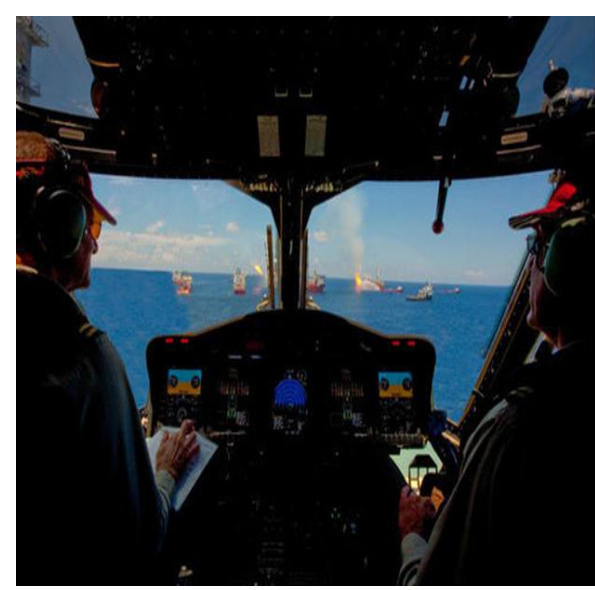

After the image was altered

Source: Korozec, 2010

Korosec (2010) argued that the images were photo shopped in a silly and shoddy way. She went on to say: "Which is too bad because the Photoshop blunders are unnecessary, cast further doubt on BP and erase whatever miniscule image boost BP received when Bob Dudley took over the Gulf oil spill response" (Korosec, 2010).

The public was again angered by BP's explanation for the altered images posted on BP's official "Gulf of Mexico Response" website. BP explained that its photographic department uses Photoshop for certain purposes: "typical purposes include colour correction, reducing glare and cropping. In a few cases, cut-and-paste was also used in the photo-editing process" (Hough 2010). BP also said although it was a private company, it had instructed the photographer who created the images to refrain from the cut-and-paste techniques in the future. In an attempt to address the allegations BP put both the original and altered image on the BP Flickr account, 
stating that BP's contract photographers had used Photoshop to edit images. Korozec (2010) again underlined the legitimacy crisis BP was facing by stating:

\begin{abstract}
The public has become increasingly sceptical of the photography in recent years, which means shoddy Photoshop or questionable images are noticed quickly. Like BP, any company can admit the mistake and change its policy, but those images and the mistrust of the brand remains.
\end{abstract}

\title{
7.3 Results and discussion
}

BP's right to operate in the Gulf of Mexico was questioned when 11 workers died and the company was seen as being complacent when first learning of the oil spill. The fact that BP's performance was questioned meant that the company faced a legitimacy crisis. This was exacerbated by the live video feed of the oil spill (Event 1) and the altered images (Event 2). This section examines qualitative statements and images in the annual and sustainability reports to determine and understand what postures $\mathrm{BP}$ adopted when responding to the crisis.

\subsection{The posture BP adopted to respond to the Deepwater Horizon incident}

Drawing on Boyd (2000), BP's response to the Deepwater Horizon incident can be viewed as actional legitimation. BP had to restore its legitimacy, because the incident that happened occurred as a direct result of BP's operational policy and actions in undertaking risky deepwater drilling operations.

From web comments taken together with mainstream media criticism (Annexure $A$ ) it is clear that the messages in the public arena about BP were not favourable, meaning BP faced a legitimacy crisis. This was acknowledged by BP in its 2010 annual report (p. 39), where the company confirmed that its reputation had been damaged, "which places BP at risk". This was further reinforced in the 2010 sustainability report, when where it stated that the Deepwater Horizon incident was a corporate crisis "that called BP's sustainability into question" (BP Sustainability Review, 2010:2). Further evidence of BP's acknowledgement of the important role organisational legitimacy plays in its operations can be found in the 2010 Summary Review (p. 15) where Dudley, the CEO, stated:

Does BP get it? ... We may not have communicated it enough at times, but yes we get it. Our fundamental purpose is to create value for our shareholders, but we also see ourselves as part of society, not apart from it

$\mathrm{BP}$ used a posture of differentiation to respond to the crisis. BP shifted the blame for the crisis to the world's demand for oil. In the chairman's letter Svanberg (BP Annual Review, 2010:5) stated: "BP is able to meet the world's growing need for energy, but we can only do this if we have the trust of society". The annual report contained the following similar language: "Global energy demand continues to rise, so the world needs BP and others to meet these challenges" (BP Summary Review, 2010:12). To better understand the context of the statement, the 2009 annual report was examined. In his 2009 chairman's report (BP Annual Review, 2009:2), Svanberg indicated BP's need to respond to the increased energy demand, because, as he remarked, "sharing the benefits of energy with communities around the world represents important human progress". This theme was continued in the 2010 annual report (review) (p. 12) when shareholders were reminded that BP has to take the risks it does, as international oil companies today have access to a much smaller share of the world's oil reserves. 
Differentiation in the form of scapegoating was also used in BP's response to the crisis. BP stated that its comprehensive internal investigation concluded that a sequence of failures involving a number of different parties led to the explosion and fire (BP Annual Review, 2010:1). Here the company is attempting to shift the blame, even if partially, to its suppliers. Scapegoating can also be seen when Dudley (BP Sustainability Review, 2010:2) says "we are now focussed on building a safer and stronger BP everywhere we work. This determination will drive how we manage risk, how we operate, how we partner with others and how we reward our employees". Again the reference to "how we partner with others and how we reward our employees" can be seen as attempts to find scapegoats in either people or systems.

The risk associated with BP's operations is stressed in both the 2009 and 2010 annual reports. The use of the words "In doing this we can never eliminate every hazard" (BP Annual Review, 2010:12) means that adopting a posture of denial, in the form of 'we are not guilty', was not feasible. Knowledge of the risk of its offshore drilling operations is also evident when BP claimed in the 2009 Annual Review (p. 5) that it is one of the few organisations that has the expertise to take on operations that others "either can't do or choose not to do". Hayward (BP Annual Review, 2009:4) also said that its successes made BP the largest producer and leading resource holder in the Gulf of Mexico. If expertise in deep-water drilling is viewed as BP's competitive advantage, any questions about its ability to conduct its operations safely is a challenge to the company's legitimacy.

According to Epstein (1972), an organisation is seen as legitimate if the public perceives it as useful and responsible. While the usefulness of the BP oil production was underlined by statements in both the annual and sustainability reports (2009 \& 2010), comments in the media following the incident indicated that the public did not see the company as acting responsibly.

In the 2010 annual report, the chairman (p. 1) and CEO (p. 8) start with a personalised letter addressed "Dear fellow shareholder", which immediately confronts the matter of the Deepwater Horizon oil spill. This is in strong contrast to the 2009 annual reports, which were not addressed to anyone in particular. In an effort to further personalise the tragic event, Dudley referred to the Gulf as being close to his heart, as he had grown up there and had spent summers with his family swimming and fishing in the Gulf: "when I heard about the accident I could immediately picture how it might affect people who live and work along that coast" (BP Annual Review, 2010:1).

Both of these letters reveal a stance of apology: "that is dealing with the problem of their guilt by acknowledging it, largely because they have no other choice" (Hearit, 1995:508). Typical apologetic words such as "we are deeply sorry" (p. 8) were used, while at the same time there was a careful attempt to avoid any acknowledgement of company responsibility (Hearit, 1995). In the Summary Review (2010:1) the chairman stated: "The accident should never have happened. We are choked and saddened that it did". However, at no time were mistakes admitted to.

BP also used denial (in the form of "our actions were not intentional") when implying that the crisis was a freak accident. The subsea blowout was the unthinkable and the probability of it happening was a very, very low probability event (BP Annual Review, 2010).

BP also adopts a legal posture. Hearit (1994) explains that this strategy is used when the company realises that their problems will be long-term and have therefore turned over the handling of the problem to legal experts. In the CEO report, Dudley adopts a legal stance when acknowledging BP's role in this event by saying that as a responsible party, "we knew we would 
face wide ranging claims and potential fines" (BP Annual Review, 2010:3). The independent assurance statement of BP's sustainability report by the auditors Ernst and Young, which creates the impression that the auditors find BP's explanations plausible, is also consistent with a legal stance (BP Sustainability Review, 2010:42).

Focusing specifically on the posture adopted in images through the use of a semiotic lens, it appears that BP mostly adopted a denial stance out of fear of liability. This is evidenced in the fact that in contrast to the 2009 annual report, which contains many images of BP's operations, the 2010 annual report contains only one image: a group photo of the board of directors looking very professional if somewhat sombre (BP Annual Review 2010:6).

The 2010 sustainability review was used as a platform for a counterattack stance through the extensive use of images. A total of 57 photographs dealing with the disaster are contained in the sustainability review (2010). Of these, only 10 did not feature humans. The remaining photographs included two or more individuals looking either concerned or caring. These photographs are an attempt to depict BP as a caring organisation. The section of the sustainability review that dealt with the accident did not contain any photographs of humans.

\subsection{Replacement of CEO Tony Hayward}

The next major challenge BP faced during this period was the replacement of the CEO. The persona of the individual such as a CEO when delivering the apologia is important (Hearit, 1995). As Hearit (1995:508) explains, if the apologia fails, the individuals who "have publicly taken responsibility for the situation" can become the scapegoat. This appears to the case with resignation of CEO Hayward. However, a careful examination of the 2010 annual and sustainability reports makes it clear that the stance of differentiation through scapegoating was not adopted with regard to Hayward. The 2010 annual report BP adopts two stances when referencing Hayward's resignation. The first, denial, is depicted in the chairman's letter, as reflected in the following words "The board was saddened to lose someone whose long-term contribution to BP was so widely admired" (BP Annual Review, 2010:7). The second, a legal stance, is depicted in the summary directors' remuneration report. Here Hayward is referred to by his formal title Dr AB Hayward together with a note stating that he had been awarded compensation for loss of office equal to one year's salary, and a further 30000 pounds in respect of UK statutory compensation rights.

These words do not seem to indicate any form of apologetic behaviour, or scapegoating. Rather, adopting a posture of denial coupled with opinion-knowledge dissociation, it appears that BP is defending its former CEO as well as its actions in respect of Hayward. Hearit (1994:119) notes that companies use this strategy when they want to make it clear, despite other evidence to the contrary, that the public's views are "mere opinions, that do not represent actual knowledge of the event".

In order to obtain a better understanding of the context surrounding Hayward, comments and images of him taken from the 2009 annual report (review) (p. 5) were examined. Hayward was commended in the 2009 annual report for his strong leadership (p. 2). Unlike the group photograph of the board of directors in the 2010 annual report, the 2009 report contains individual photos of both the chairman, Svanberg (BP Annual review, 2009:2), and CE0, Hayward (p. 5). See Image 2. 


\section{IMAGE 2: Tony Hayward}

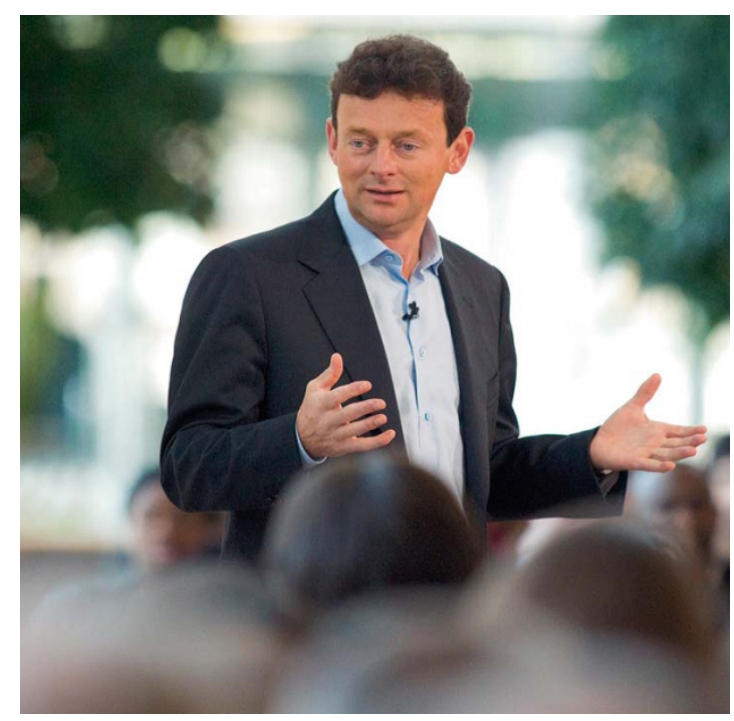

Source: BP Annual Report 2009

Using denotation and drawing on Kress (2006), Hayward can be seen as a focaliser in the image. His importance is stressed and the image gives the message that he stands out in a crowd. In the photograph he is also placed significantly higher than his audience, which is blurred out. The environment too is blurred in the image. This communicates the message that Hayward is the only one that matters - not the environment, nor the people around him. This image reflects bloggers' view of Hayward, namely that it's all about him.

\subsection{Altered Images}

Allegations surfaced that BP altered images of its clean-up operations in the Gulf (Event 2: Image 1). Korozec's (2010) blog argued that while doctored "photos don't rise to the same levels as cutting corners on safety. ... it does provide a snapshot of the culture within BP". This remark indicated that some of the public thought BP's values were clashing with their own - a sign that the company faced a legitimacy crisis.

No reference is made in either the annual report (2010) or in the sustainability report (2010) to the matter of the altered images. The posture BP adopted here is one of denial - that is, a stance that the company is not guilty. The link to BP's Flickr account (2010) providing information on the altered images adopts a posture of differentiation through scapegoating by laying blame for the altering of images on BP's contract photographers.

A summary of the findings of the postures adopted during these three crisis events is given in Annexure C.

\section{CONCLUSION}

This article draws on the theories of organisational legitimacy and image repair discourse. It had as its objective to determine through an analysis of non-quantitative disclosure and semiotics, 
in the annual and sustainability reports, the postures and reasons for the postures BP adopted when responding to the legitimacy crisis that arose from the Deepwater Horizon oil spill. The article illustrated that BP adopted a vast array of the five postures identified by Hearit (1995) in both the 2010 annual and sustainability reports. To provide a greater depth of understanding, the contexts in which the postures were adopted the 2009 annual and sustainability reports were also examined. By using Hearit's (1995) image repair strategy of focusing on the posture BP adopted, the article adds to the literature on image repair discourse theory. The literature on image repair discourse strategies has also been enhanced by supplementing Heart's image repair strategy with semiotics. This article also focused on the important role of both the annual and sustainability reports as a communication tool when an organisation's legitimacy is challenged.

The article contains a number of limitations which should be taken into account when analysing the results. The paper focuses on one particular organisation, BP, facing a huge crisis of institutional legitimacy. Further study into the application of Hearit's theory to different organisations and context is warranted.

\section{LIST OF REFERENCES}

Abrahamson, E., \& Park, C. (1994). Concealment of negative organizational outcomes: An agency theory perspective. Academy of Management Journal, pp. 1302-1334.

About.com. (2010). Ten things you need to know about the Deepwater Horizon oil spill. [0nline] Available: http://environment.about.com/od/environmentalevents/tp/10-Things-You-NeedTo-Know. (Accessed 14 August 2011).

Allan, M.W. \& Caillouet, R.H. (1994). Legitimation endeavours: Impressions management strategies used by organizations in crisis. Communication Monographs, 61(4), pp. 44-62.

Alvesson, M. (1990). Organization: From substance to image? Organizational Studies, 11(3), pp. 373-394.

Associated Press. (2010). BP CEO disputes claims of underwater oil plumes. [Online] Available: http://blog.al.com/live/2010/05/bp_ceo_disputes_claims_of_unde.html. (Accessed 3 August 2011).

Barton, L. (2001). Crisis in Organizations //, $2^{\text {nd }}$ edition. Cincinnati: College division South Western.

BBC News. (2010). Timeline: BP oil spill. [Online] Available: http://www.bbc.co.uk/news/worldus-canada-10656239. (Accessed 17 February 2010)

Benoit, W.L. (1997). Image repair discourse and crisis communication. Public Relations Review, 25(2), pp. 145-156.

Benoit, W.L. \& Brinson, S.L. (1999). Queen Elizabeth's image repair discourse: Insensitive royal or compassionate Queen?. Public Relations Review, 25(2), pp. 145-156.

Benoit, W.L. \& Henson, J.R. (2009). President Bush's image repair discourse on Hurricane Katrina. Public Relations Review, 35(1), pp. 40-46. 
Benoit, W. L. \& Lindsey, J.J. (1987). Argument strategies: Antidote to Tylenol's poisoned image. Journal of the American Forensic Association, 23(3), pp. 136-46.

Black, B. (2010). On BP's Deepwater Horizon live video feed. Environmental History, 15(4), pp. 741-745.

Botes, V.L. (2006). The perceptions of the skills required and displayed by management accountants to meet future challenges. Unpublished D.Com thesis. Pretoria: University of South Africa.

Boyd, J. (2000). Actional legitimation: no crisis necessary. Journal of Public Relations Research, 12(2), pp. 341-353.

BP (2010). Annual Review and Form 20-F 2010. [Online] Available:

http://www.bp.com/extendedsectiongenericarticle.do?categoryld=9039692\&contentld=707268 3.bp.com/ annual report. (Accessed 4 March 2011).

BP (2009). Annual review and Form 20-F2009. [Online] Available:

http://www.bp.com/extendedsectiongenericarticle.do?categoryld=9039692\&contentld=707268 3.bp.com/ annual report. (Accessed 4 March 2011).

BP (2010). Summary Review. [Online] Available:

http://www.bp.com/assets/bp_internet/globalbp/globalbp_uk_english/set_branch/STAGING/c ommon_assets/downloads/pdf/BP_Summary_Review_2010.pdf. (Accessed 4 March 2011).

BP (2010). Sustainability Review 2010. [Online] Available:

http://www.bp.com/sectiongenericarticle.do? categoryld=9040280\& contentld=7073554.

(Accessed 4 March 2011).

BP (2009). Sustainability Review 2009. [Online] Available:

http://www.bp.com/sectiongenericarticle.do?categoryld=9040280\& contentld $=7073554$.

(Accessed 4 March 2011).

Briñol, P., Petty, R.E. \& Wagner, B. (2009). Body posture effects on self-evaluation: A selfvalidation approach. European Journal of Social Psychology, 39(6), pp. 1053-1064.

Brinson, S.L. \& Benoit, W.L. (1999). The Tarnished Star Restoring Texaco's Damaged Public Image. Management Communication Quarterly, 12(4), pp.483-510.

Bryant, M. \& Hunter, T. (2010). BP and public issues (mis)management. Ivy Business Journal, October [Online] Available: http://www.iveybusinessjournal.com/topics/leadership/bp-andpublic-issues-mismanagement. (Accessed 28 December 2012).

Cheney, G. (1992). The corporate person (re)presents itself as quoted in Boyd. Journal of Public Relations Research, 12(4), pp. 341-355.

Coombs, W.T. (2007). Protecting organizational reputations during a crisis: the development an application of situational crisis communication theory. Corporate Reputation Review, 10(3), pp. $163-176$

Deegan, C., Rankin, M. \& Tobin, J. (2002). An examination of the corporate social and environmental disclosures of BHP from 1983-1997: A test of legitimacy theory. Accounting, Auditing \& Accountability Journal, 15(3) pp.312-43.

de Gravelles, J.W. \& de Gravelles, J.N. (2011). The Deepwater Horizon rig disaster: Issues of personal injury and death. Tulane Law Review, 84(4), pp. 1075. 
Dowling, J. \& Pfeffer, J. (1975). Organizational legitimacy: social values and organizational behaviour. Pacific Sociological Review, 18(1), pp. 122-136.

Eccles, R.G. \& Krzus, M.P. (2010). One Report. New Jersey: John Wiley \& Sons.

$\varepsilon c o$, U. (1979). A theory of semiotics. Indiana: Indiana University Press.

Eilperin, J. (2010, May 5). US exempted BP rigs from impact analysis. Washington Post, retrieved from http://www.washingtonpost.com.

Epstein, E.M. (1972). The historical enigma of corporate legitimacy. California Law Review, pp. 1701-1717.

Fitzpatrick, K.R. \& Rubin, M.S. (1995). Public relations vs. legal strategies in organizational crisis decisions. Public Relations Review, 21(1), pp. 21-33.

Frandsen, F. \& Johansen, W. (2011). Rhetoric, climate change, and corporate identity management. Management Communication Quarterly, 20(2), pp. 1-20

Glantz, M. (2010). The Flyod Landis doping scandal: Implications for image repair discourse. Public Relations Review, 36(2), pp. 157 -163.

Georgiou, 0. \& Jack, L. (2011). In pursuit of legitimacy: A history behind fair value accounting. British Accounting Review, 43, pp. 311-23.

Goffman, $\varepsilon$. (1971). Relations in public: microstudies of public order. New York: Basic Books.

Gosden, $\varepsilon$. (2013, February 5). BP gulf of Mexico spill cost could top $\$ 90 \mathrm{bn}$. Telegraph Available: http://www.telegraph.co.uk/finance/newsbysector/energy/oilandgas/9851376/BP-Gulf-ofMexico-spill-costs-could-top-90bn-after-fresh-claims.html.

Guarino, M. (2010). Gulf oil spill update: What's known about cause and effects The Christian Science Monitor.

Hearit, K.M. (1994). Apologies and public relations crises at Chrysler, Toshiba and Volvo. Public Relations Review, 20, pp. 113-125.

Hearit, K.M. (1995). Mistakes were made: Organizations, apologia and crises of social legitimacy. Communication Studies, 46(1-2), pp. 1-17.

Hearit, K.M. (2001). Corporate Apolgia. In Heath, R. L. (ed.) Handbook of Public Relations. California: Sage Publications (pp. 501-511).

Hearit, K.M. (2006). Crisis Management by Apology. Lawrence Erlbaum Associates, Inc. New Jersey.

Hearit, K.M. \& Brown, J. (2004). Merrill Lynch: Corporate apologia and fraud. Public Relations Review, 30(4), pp. $459-466$.

Heller, S. (2004). Design Literacy, Allworth press, New York.

Hirsh, P.M. \& Andrews, J.A.Y. (1984). Administrators' responses to performance and value challenges: stance symbols and behaviours. In Sergiovanni, T.J. \& Corbally, J.E. (eds.) Leadership and Organizational culture. Routledge London. (pp. 173-4)

Hocks, M.E. (2003). Understanding visual rhetoric in digital writing environments. College Composition and Communications, 54(4), pp. 629-656. 
Hooghiemstra, (2000). Corporate Communication and Impression Management. In Andriof, J., Waddock, S., Husted, B. \& Rahman, S. (eds.) Unfolding Stakeholder Thinking 2: relationships, Communication and Reporting. Sheffield, UK: Greenleaf Publishing.

Hough, A. (2010). BP admits it 'Photoshopped' official images as oil spill 'cut and paste' row escalates. The Daily Telegraph. [Online] Available:

http://www.telegraph.co.uk/earth/energy/oil/7904221/BP-admits-it-Photoshopped-officialimages-as-oil-spill-cut-and-paste-row-escalates.html. (Accessed 22 June 2011).

Huffingtonpost, (2010). BP CE0 I want my life back. [Online] Available:

http://www.huffingtonpost.com/2010/06/01/bp-ceo-tony-hayward-video_n_595906.html. (Accessed 20 June 2011).

Jiang, H., Li, Z.N., \& Drew, M.S. (2007). Recognizing posture in pictures with successive convexification and linear programming. MultiMedia, IEEE, 14(2), 26-37.

Kaufman, J.B., Kesner, I.F. \& Hazen, T.L. (1994). The myth of full disclosure: A look at organizational communications during crises. Business Horizons, 37(4), pp. 29 -39.

King, R.0. (2010). Deepwater Horizon oil spill, disaster: risk, recovery and insurance implications. Congressional Research service. [Online] Available:

http://www.cnie.org/NLE/CRSreports/10Aug/R41320.pdf. (Accessed 10 August 2011).

Korosec, K. (2010). BP and the Gulf oil spill: misadventures in photoshop. [Blog commentary]. [Online] Available: http://www.bnet.com/blog/clean-energy/bp-and-the-gulf-oil-spillmisadventures-in-photoshop/2091. (Accessed 10 July 2011).

Kress, G. (2006). Reading images: The grammar of visual design. London: Routledge.

Litvin, S., Goldsmith, R.E. \& Pan, B. (2007). Electronic word of mouth in hospitality and tourism management. Tourism Management. [Online] Available: http://www.otd.cofc.edu/pn.

(Accessed 17 April 2012)

Magner, M. (2011). Poisoned Legacy. New York: St Martin's Press,

Maresh, M. \& Williams, D.E. (2010). Oil industry crisis communication. In Coombs, T.W. \& Holladay, S.J. (eds.) The Handbook of crisis communication. Oxford: Blackwell Publishing (pp. 285-300).

Metzler, M.S. (2001). Responding to the legitimacy problems of big tobacco: An analysis of the people of Phillip Morris' image advertising campaign. Communication Quarterly, 49(4), pp. 336381.

Milbank, D. (2010). BP needs a crude awakening. Washington Post, 12 May, NewzText.

Ogden, S. \& Clarke, J. (2005). Customer disclosures, impression management and the construction of legitimacy. Accounting, Auditing \& Accountability Journal, 18(3), pp. 313 -345.

Raby, M. (2010). BP alters image of Gulf oil spill centre. [Online] Available:

http://www.tgdaily.com/business-and-law-brief/50750-bp-alters-image-of-gulf-oil-spillcenter. (Accessed 28 September 2011).

Rogers, R.K., Dillard, J. \& Yuthas, K. (2005). The accounting profession: Substantive change and/or image management. Journal of Business Ethics, 58(1), pp. 159-176. 
Samkin, G. (2012). Changes in sustainability reporting by an African defence contractor: a longitudinal analysis. Meditari Accountancy Research, 20(2), pp. 134-166.

Samkin, G., Allen, C. \& Wallace, K. (2010). Repairing organisational legitimacy: the case of the New Zealand police. Australian Accounting Business and Finance Journal, 4(3), pp. 23 -44.

Samkin, G. \& Schneider, A. (2010). Accountability, narrative reporting and legitimation: the case of a New Zealand public benefit entity. Accounting, Auditing \& Accountability Journal, 23(2), pp. 256-289.

Scare (2010). BP CEO Tony Hayward: Oil spill impact modest. [Online] Available: http://videocafe.crooksandliars.com/scarce/bp-ceo-tony-hayward-oil-spill-impact-very-m. (Accessed 28 July 2011).

Schultz, P.D., \& Seeger, M.W. (1991). Corporate centred apologia: lacocca in defence of Chrysler. Speaker and Gavel, 28(1-4), pp. 50-60.

Scott, M. (1994). Images in advertising: the need for a theory of visual rhetoric. Journal of Consumer Research, 21(2) pp. $252-273$.

Shocker, A.D. \& Sethi, S.P. (1974). An approach to incorporating social preferences in developing corporate action strategies. The unstable ground: Corporate social policy in a dynamic society, 67, p.80.

Schuman, M.C. (1995). Managing legitimacy: Strategic and intuitional approaches. The Academy of Management Review, 20(3), pp. $571-610$.

Sigglekow, N. (2007). Persuasion with case studies. Academy of Management Journal, 50(1), pp. 20-24.

Smith, L., Smith, M. \& Ashcroft, P. (2010). Analysis of environmental and economic damages from British Petroleum's Deepwater Horizon oil spill. Available at SSRN 1653078.

Snyder, C.R., Higgins, R.L. \& Stucky, R.J. (1983). Excuses: Masquerades in search of grace. New York: Wiley.

Summers. (2010). I'd Like My Life Back [Online: video podcast]. Available:

http://www.youtube.com/watch?v=MTdKa9eWNFw\&feature=player_embedded. (Accessed 1 June 2011).

Summershay, K. \& De Villiers, C. (2012). Oil company annual report disclosure responses to the 2010 Gulf of Mexico oil spill. Journal of the Asia-Pacific Centre for Environmental Accountability, 18(2), pp. 103-130.

Stuever, H. (2010) BP presents: One slick horror film. Washington Post, 26 May, NewzText,

Svensson, P. (2009). Embracing left and right: image repair and crisis communication in a polarized ideological milieu. Management Communication Quarterly, 22(4), pp. 555-576.

Sweet, C. (2012). BP to Pay Alaska \$255 Million for 2006 Spills. The Wall Street Journal, [Online] Available: http://online.wsj.com/article/BT-C0-20121108-723779.html. (Accessed 28 December 2012).

Taylor, M. (2009). Civil society as a rhetorical public relations process. In Heath, R.L., Toh, E.L. \& Waymer, D. (eds). Rhetorical and Critical Approaches to Public Relations I/. New York: Routledge (pp.76-91). 
Times Online. (2010). Embattled BP chief: I want my life back. The Sunday Times [Online] Available:

http://business.timesonline.co.uk/tol/business/industry_sectors/natural_resources/article71 41137.ece. (Accessed 3 May 2011).

Yoon, Y. (2005). Legitimacy, public relations, and media access: Proposing and testing a media access model. Communication Research, 32(6), pp. 762-793.

Vasquez, G.M. \& Taylor, M. (2001). Research perspectives on the public. In Heath, R.L. (ed). Handbook of Public Relations. CA: Sage. (pp.137-154).

Ware, B.L. \& Linkguel, W.A. (1973). They spoke in defense of themselves: On the generic criticism of apologia. Quarterly Journal of Speech, 59, pp. 273-283. 
Botes \& Samkin

\section{ANNEXURE A}

Time line of major events affecting BP during Deepwater Horizon oil spill (2010)

\begin{tabular}{|c|c|c|}
\hline April 20 & $\begin{array}{l}\text { Deepwater Horizon experiences an explosion and fire on the } \\
\text { rig, killing } 11 \text { and injuring } 17 \text { people. Crude oil starts to spill } \\
\text { into the gulf of Mexico }\end{array}$ & Press release \\
\hline April 22 & Deepwater Horizon sinks & Press release \\
\hline April 25 & $\begin{array}{l}\text { Initial estimates of oil flow are } 1000 \text { barrels a day, later } \\
\text { revised to } 5000 \text { barrels a day. }\end{array}$ & $\begin{array}{l}\text { Interview by officers } \\
\text { on radio and } \\
\text { television }\end{array}$ \\
\hline April 30 & $\begin{array}{l}\text { CEO Hayward indicates that company will take complete } \\
\text { responsibility and compensate all legitimate claims and pay } \\
\text { for clean-up. }\end{array}$ & $\begin{array}{l}\text { Interview by officers } \\
\text { on radio and } \\
\text { television }\end{array}$ \\
\hline May 2 & Fishing is banned in the water surrounding the spill & Press release \\
\hline $\begin{array}{l}\text { May } 2- \\
\text { July } 15\end{array}$ & $\begin{array}{l}\text { Various efforts to stop oil leak fails. Total oil flow now } \\
\text { estimated at } \\
20000 \text { barrels per day. }\end{array}$ & Press release \\
\hline May (late) & $\begin{array}{l}\text { Government insists that live video feed of oil leak is shown to } \\
\text { USA public on daily basis }\end{array}$ & $\begin{array}{l}\text { Press release on } \\
\text { television }\end{array}$ \\
\hline May 28 & $\begin{array}{l}\text { Six-month ban on Deepwater drilling is initiated by US } \\
\text { government }\end{array}$ & Press release \\
\hline June 1 & ૮દ0 Hayward makes comment: "I’d like my life back" & $\begin{array}{l}\text { Interview by officers } \\
\text { on radio and } \\
\text { television }\end{array}$ \\
\hline \multirow[t]{2}{*}{ Junel6 } & $\begin{array}{l}\text { CEO and Chairman establish a } \$ 20 \text { billion fund to pay for } \\
\text { damages and BP announces it will pay } \$ 100 \text { million to workers } \\
\text { laid off because of ban on Deepwater drilling. }\end{array}$ & Press release \\
\hline & $\begin{array}{l}\text { BP posts images of its Gulf of Mexico oil spill response centre } \\
\text { on its website. }\end{array}$ & BP website \\
\hline June 18 & CEO Hayward appears before US congress & $\begin{array}{l}\text { Interview by officers } \\
\text { on radio and } \\
\text { television }\end{array}$ \\
\hline June 20 & Blogger spots that images have been altered & Website \\
\hline June 21 & BP admits that images have been altered & Press release \\
\hline July 15 & Oil leak is completely stopped by a cap. & TV Footage \\
\hline July 27 & CEO Tony Hayward resigns & Press Release \\
\hline Sept 15 & $\begin{array}{l}\text { CEO Hayward speaks to British parliament and denies cost } \\
\text { cuts were the cause of oil spill and defends safety culture at } \\
\text { BP }\end{array}$ & $\begin{array}{l}\text { Interview by officers } \\
\text { on radio and } \\
\text { television }\end{array}$ \\
\hline October 1 & Bob Dudley takes over as new C $\subset 0$ & Press release \\
\hline
\end{tabular}




\section{ANNEXURE B}

Estimates of economic and environmental damages to external parties because of Deepwater Horizon oil spill

\section{Panel A:}

Description

Amount (US\$)

Damages to the commercial fishing industry

4.36 billion

Damages to the tourism industry

3.8 billion

Loss in coastal real estate values

4.32 billion

Panel B

Description Amount

Number of National parks and National Wildlife Refuges at immediate risk

Pounds of oil debris removed from land in Mississippi, Alabama and Florida

Visibly oiled animals found dead through October 14, 2010:

Birds

Sea turtles

Mammals

Visibly oiled animals found alive through October 2010 :

Birds

Sea Turtles

Mammals

Source: Smith, Smith and Ashcroft (2011:22) 


\section{ANNEXURE C}

Hearit's (1995) postures visible in BP's annual and sustainability reports

\begin{tabular}{|c|c|c|c|}
\hline Posture type & $\begin{array}{c}\text { Deepwater } \\
\text { Horizon Incident }\end{array}$ & $\begin{array}{c}\text { CEO Tony Hayward's } \\
\text { resignation }\end{array}$ & $\begin{array}{l}\text { Altered images of } \\
\text { clean-up operations }\end{array}$ \\
\hline 1.Denial & & & \\
\hline (a) We are not guilty. & No & No & Yes \\
\hline $\begin{array}{l}\text { (b) Our actions were not } \\
\text { Intentional (opinion- } \\
\text { knowledge dissociation) }\end{array}$ & Yes & Yes & No \\
\hline $\begin{array}{l}\text { (c) We fear liability } \\
\text { therefore we deny guilt } \\
\text { irrespective of public } \\
\text { evidence }\end{array}$ & Yes & No & No \\
\hline $\begin{array}{l}\text { 2.Counterattack } \\
\text { Deny guilt and attempt } \\
\text { to transfer it to the } \\
\text { accusers. }\end{array}$ & Yes & No & No \\
\hline 3.Differentiation & & & \\
\hline $\begin{array}{l}\text { (a) Transfer guilt from } \\
\text { organisation to an } \\
\text { individual ( scapegoat). }\end{array}$ & Yes & No & No \\
\hline (b) Defeasibility & No & No & No \\
\hline $\begin{array}{l}\text { 4.Apology } \\
\text { Acknowledge because } \\
\text { you have no choice but } \\
\text { do not acknowledge } \\
\text { responsibility }\end{array}$ & Yes & No & No \\
\hline $\begin{array}{l}\text { 5. Legal } \\
\text { We understand that this } \\
\text { is a matter which will } \\
\text { have long-term } \\
\text { consequences for the } \\
\text { organisation }\end{array}$ & Yes & Yes & No \\
\hline
\end{tabular}

